\title{
THE CHALLENGES OF GIRL-CHILD EDUCATION AND ALTERNATIVE JOBS IN NIGERIA
}

\author{
TINUOLA FEMI
}

\begin{abstract}
The real life experiences of Nigerian girl children indicate that the current Global Economic Crisis (GEC) has worsened their situation. This study examines the effects of GEC on the education of the girl-child and their engagement in alternative jobs. Data were obtained from 1,200 female children between 6-14 years of age, selected with a purposive random sampling-technique, who were engaged in hawking in three Nigerian states. About twenty parents were also selected to go through in-depth interview sessions. They responded to a semistructured questionnaire. Findings show that $45 \%$ of girls had recently dropped out of school and engaged in hawking to enhance their lives and that of their family household, making an average daily gain of one U.S. dollar. They hawk in crowded markets, hotels and at busy road junctions. There are reported cases of child-sexual abuse. Four percent of girls performing paid housework were impregnated, resulting in clandestine abortions. An improvement in the socioeconomic conditions of parents and a social protection policy for girl-children are recommended.
\end{abstract}

KEYwORDs children, hawking, labor, education, Nigeria, child abuse

\section{BACKGROUND}

The world demographic profile shows that Nigeria, the tenth most populous country, represents one-fifth of the population of the African continent. Various population censuses have consistently shown that children (0-14 years of age) constitute a significant proportion of the population in Nigeria. The first census, conducted in 1962-63, showed that out of 55.7 million people, $43.1 \%$ were children. The result of the 1991 population count indicates that out of

1Tinuola Femi, PhD is Professor of Sociology at the Department of Sociology, Kogi State University, P. M.B 1008, Anyigba Nigeria; e-mail: adufem2000@yahoo.com 
about 88.6 million people, about $45 \%$ were children ( $0-14$ years of age). The details of the 2006 census are currently being awaited, but preliminary reports were released in early 2009 with a call for all and sundry to be "more focused on giving to the promotion of children's education and the discouragement of negative practices related to children (National Population Commission, 2006). The reports show that children represent a significant proportion of Nigeria's population. These child-related demographic data have led to increased calls for a separate government ministry to handle issues related to the welfare of children through which some rights of the child can be guaranteed.

The UN convention on the Rights of the child provides an introduction to children's rights and recognizes childhood as an important part of life and highlights the special need for child protection, education, nutrition and development. A major highlight of the convention is "free and compulsory education for all children and protection from economic exploitation".

The UN General Assembly International Covenant on Civil and Political Rights resolution in 1996, article 24 of The Charter of Fundamental Rights of the European Union, The African Charter on the Rights and Welfare of the child (to which Nigeria is a signatory), the Child Rights Act approved by the Nigeria Parliament which adapts the UN convention and The AU charter on the Rights of the child all stipulate that "the child is entitled to receive education, and shall be protected against all forms of neglect, cruelty and exploitation".

The achievement of the Child's Rights Act in education has suffered a serious setback, especially in the countries of sub-Saharan Africa as a result of the current Global Economic Crisis (GEC). This has hit the import-dependent economy of sub-Saharan Africa countries hard, with resulting consequences for the welfare of Nigerian children. The poor welfare of the Nigerian child is an effect of the socio-economic conditions of their parents. Various reports have shown that Nigerian children are increasingly engaging in alternative jobs for survival.

A 2006 study by the International Labor Organization (ILO) found a staggering fifteen million children under the age of fourteen engaged in various forms of labor across Nigeria. These children were exposed to long hours of work in dangerous, unhealthy and competitive environments. This, according to the reports, results from the inability of parents and governments to fully take responsibility for child welfare. Real life experiences have shown that governments at all levels have failed to provide totally free qualitative education for children. The situation has continued to worsen as a result of the current Global Economic Crisis. In 2000, Nigeria joined over 170 countries 
that met in Dakar, Senegal to reaffirm their commitment to deliver education for all citizens by 2015. The second aim of the Millennium Development Goal on Education is to provide "all children with access to education". This is an important goal because it is believed that through qualitatively modern formal education, future generations will have the ability to reduce or put an end to world poverty and help to achieve worldwide peace and security. The goal of education for all children, as agreed, could only be achieved through a systematically organized school system, with regulated periods of education and a standardized curriculum and content. There is a need to ascertain the extent to which Nigeria is committed to achieving the goals of the various charters regarding children through a social survey. The situation with children may not have improved considering various reports from officials of government agencies, non-governmental agencies, international donor agencies and other stakeholders involved in the welfare of children.

Information posted on the Internet by African Press on 25 April 2008 quoted the Nigerian Minister of Education, who said "it was lamentable that about eleven million children, out of which 4.7 million were of primary school age and 5.3 million of secondary school age, roamed the streets in the country" and were engaged in all forms of child labor to support their education and family household. A newspaper article in PUNCH from 25 March 2008, page 14 , credited to the media advisory unit of UNICEF indicated that "no less than 10 million children of school age are out of school in Nigeria" (UNICEF, 2009).

The Acting Secretary of the National Commission for Mass Literacy, Adult and Non-Formal Education, Alhaji Jibrin Paiko, revealed in The Tribune Newspaper on 9 September 2009 that about 46,340,000 Nigerians out of about 140 million cannot read or write.. "He indicated that worldwide, in addition to 776 million illiterate adults, another 75 million children do not go to school (The Tribune Newspaper, 9 September 2009)

In 2006, key UNICEF data showed that an estimated 93 million children worldwide are subjected to violence, exploitation and abuse. The report showed an estimated 93 million children of primary school age were not attending school, and out of these, 48.5 million were girls.

UNICEF reported in 2006 that Nigerian children, some of whom either had not attended school formally or who had dropped out of school, were engaged in various forms of labor either for their education or to support their family households. Specifically, report data showed that Nigerian children work in the following occupations: Street vendors (64\%), Beggars (13\%), Shoe shiners (4\%), Car washers (6\%), Scavengers (5\%) and Foot washers (8\%) (UNICEF, 2009). Children are engaged in alternative jobs to support the 
family household and to collect money for secondary and tertiary education. Most of the laws passed by the federal legislature on child education require similar passage at the state Houses of Assembly for domestic adoption and implementation. However, the domestic adoption of the Laws on children and their implementation are influenced by factors such as the political will of leaders and the state economy. In Nigeria, the Child Right's Act was passed by the National Assembly and signed into law by the President. In some states, the bill has been signed into law and it is now a crime to engage a child under eighteen as house help. The law also seeks to eliminate street hawking by children.

With various charters concerning several legal frameworks for action signed by the Nigerian government, there is a need for independent social research to assess the level of compliance and implementation with these pieces of law in attempting to formulate a pragmatic description of the welfare of Nigerian children. A social field survey, independent of government influence, such as this one, will achieve this purpose.

\section{RESEARCH DESIGN}

\subsection{Objectives}

This study examines the effect of the Global Economic Crisis on the education of the girl-child and their engagement in alternative jobs. The working objectives are to examine:

1. The level of education of the girl child

2. The incidence and prevalence of alternative jobs and the places where such jobs exist

3. The dangers of street hawking for the girl-child

\subsection{Positions}

1. The socio-economic level of children who have dropped out of school significantly correlates to the socio-economic level of the parents caused by the GEC

2. The incidence of child sexual abuse is directly proportional to the locations of 'alternative' jobs

3. The urge to go back to schools is significantly related to the gains made from menial job 


\subsection{Methods}

The study was conducted in two political states in North Central Nigeria with the Hausa, Ebira, Igala, Idoma, Tiv and Filani ethnic groups. About 200 children (6-14 years old) were randomly sampled from each of the ethnic groups, amounting to a total of 1,200 children for the entire study. The instrument was a semi-structured questionnaire, divided into demographic characteristics, education history, parents' socio-economic conditions and alternative jobs. The instrument contained $60 \%$ close-ended and $40 \%$ openended questions to give room for respondent-initiated responses. The instrument was validated by a group of experts in Education, Child Development and Social Sciences from three state universities. A reliability coefficient of 0.98 for the instrument was achieved with the use of chi-square. The instruments were administered by six trained field workers, who were drawn from each of the ethnic groups to facilitate better responses from illiterate respondents. Data were analyzed with the use of the Statistical Package for the Social Sciences (SPSS) software. Data were reported in frequency / percentages in tabulation while relationships between variables were tested and ascertained with the use of the chi-square and Pearson coefficient.

\section{FINDINGS}

This section discusses data obtained from the fieldwork. It is divided into three sections to sequentially address the objectives of the study.

\subsection{Characteristics}

\section{Selected Children}

This study was conducted among 1,200 children in two selected states in North Central Nigeria. Data show that the majority of the children (62\%) were in the 11-14 year age bracket while the remaining $38 \%$ were between 6-10 years of age. The mean age of the respondents was 10.8 years. Half of the sample was Muslim while 38\% were Christian, and just $4 \%$ were adherents of traditional ethnic religions; the remaining $8 \%$ did not identify with any religion. Of the children, $68 \%$ had both parents while $32 \%$ had at most one parent or had lost both parents either to death, divorce or marital separation.

Slightly above half (54\%) had had sex while $46 \%$ had not engaged in 
sexual activity. Further background investigation revealed that $83 \%$ had their first sexual experience between 12-14 years of age while 15\% first had sex between 9-11 years of age, and just 2\% first had sex between the ages of 6-8. The average age of first sexual encounter was 12.5 years.

\subsection{Children's educations hystory}

\section{Schooling Background}

The question whether the children had ever attended school was asked to ascertain educational status. Findings show that $75 \%$ had once enrolled in a primary school system under the Universal Basic Education Scheme; the remaining $25 \%$ had not attended any formal schooling - out of which $18 \%$ are currently in Quranic education. Due to a campaign by the Federal Ministry of Education, enrollment in primary schools has increased over the years with more challenges in Northern Nigeria, where religious education takes priority. A breakdown of the data shows that, of Yorubas, $96 \%$ were in formal schools. Igala (55\%), Tiv (58\%), Ebira (50\%) and Hausa/Filani (12\%) school attendance figures relate to other social variables related to the young girls. In a study, Audu, Geidam and Harma (2001) found that 33.4\% of the sampled girls who were sexually assaulted in Nigeria had no formal education, and $78.5 \%$ were currently not going to school. The study found that sexual assault was more likely to occur to girls who were younger than twelve.

Data show that $40 \%$ of children were in Primary school (ages $1-3,15 \%$; ages $4-6,25 \%$ ) while the remaining $60 \%$ were at secondary school (Junior Secondary School 45\%, Senior Secondary School 1, 15\%). Under the school system in Nigeria, the government's Universal Basic Education Program covers Primary grades 1-6 and the first three years of Junior Secondary School.

\section{School Expenses}

Under the UBE Educational program, pupils in primary school and JSS 1-3 do not pay school fees, and in some cases, a few exercise books are distributed to them, depending on the political will and commitment of the ruling government. However, parents are responsible for other incidental expenses such as school uniforms, sandals, textbooks and health care. In 2008, some states began a free meal program for pupils in primary schools, 
but have reportedly stopped due to the current GEC, which has caused state governments to become unable to meet their financial obligations. The tuition and associated educational fees of the selected children in Senior Secondary Schools were paid by father (15\%) mother (48\%), both parents $(7 \%)$, relatives $(5 \%)$ or self $(25 \%)$.

\section{Nature of School Attended}

In the states where this research was conducted, pupils have the option of attending morning or evening schools. Questions were asked to ascertain the nature of schools they attended to establish a link to the timing of their involvement in activities outside school. About 35\% of pupils attended evening schools while $65 \%$ were at morning schools. Those who attended evening schools reportedly engaged in other activities to boost their family's household income and to deal with other needs regarding schooling. Data reported that factors which influence school attendance included nutrition, housing, and health. About $74 \%$ of those who attended formal schools were in public primary and secondary schools; the remaining $26 \%$ were at private schools.

\section{Currently in School}

A question concerning whether those who had ever attended school were currently attending school was asked. Responses indicate the gap and thus the percentage of children that dropped out of school within that period. Out of those who reported having ever attended school, 15\% had dropped out completely, $30 \%$ had changed from morning to evening classes, while the remaining 55\% are still in school.

\section{Dropped out of School}

An investigation into why the $15 \%$ of children dropped out of school clearly shows that one-quarter left school as a result of their inability to buy relevant text books for various subjects, school uniforms, sandals and/or food to enable effective learning in the classroom. It was reported that some of them were beaten by their teachers on several occasions for wearing torn and sub standard school uniforms, bathroom slippers, non standard clothes 
to school, in addition to being unable to buy relevant books for school. Some children reported that those who were initially responsible for their education were either directly or indirectly affected by the current GEC. Almageris are children sent into the streets to beg for food. The survey report suggests that the danger of girls dropping out of school and being forced into child labor is linked to evidence that in most states in Northern Nigeria families give preference to boys' education to the detriment of girls'.

A portion of the children dropped out of school because of the many months of stay-at-home action embarked upon by the teachers in one of the states. The children indicated that for about six months, teachers in both primary and secondary schools engaged in a strike action against the non implementation of the Teachers Salary Structure (TSS), in which the Teachers' Union agreed with the government. State governments blamed their inability to implement TSS on the dwindling revenue accruing from the Federal Account. This is an effect of the drop in the price of crude oil, Nigeria's major export earner on the world market, as a result of the current GEC. In one of the States, teachers in primary and secondary schools took part in an industrial stayat-home action between November 2008 and May 2009. The government, which earlier promised to pay them their salaries, could not fulfill the promise as a result of the GEC which affected their incomes. For a very long period, children took to the street to hawk products to meet their needs. About $15 \%$ of students dropped out of school because they could not keep up with class work, having missed too many days and not being able to catch up. This report states that most children leave school within a few years after completing primary school or a few years into secondary school. While some experience significant academic challenges resulting from truancy and lack of required academic materials, most students could have succeeded in school. However, over $50 \%$ of dropouts recognized that graduating from school was essential to their success in securing good quality employment in the future. While the reasons students drop out vary, the general categories are consistent with direct or indirect links to the current GEC which affects the country's revenue.

\section{Year Dropped out of School}

About $15 \%$ of the children sampled reportedly dropped out of school in $2006,30 \%$ left school in 2007 while the remaining 55\% dropped out in 2008 to seek alternative means of survival outside of school. Children dropped out of school because of real life events caused by the current GEC as they had 
to get a job, to care for themselves or for other family members. Of all the children surveyed, over $50 \%$ would have preferred to complete their education and get a school leaving certificate.

\section{Desire to go back to School}

If the government and other stakeholders were to provide all school facilities free to students, about $70 \%$ percent of child drop-outs would go back to school while $30 \%$ would continue their present businesses, as indicated by their responses. The $30 \%$ say they would rather have assistance in boosting their trades rather than go back to school, feeling that the former option would lead to a brighter future. About $56 \%$ of those who dropped out of school actually indicated that they engaged in other forms of business to continue living and had no intention of going back to school. The remaining $44 \%$ would go back if given financial backing from their sponsors and if the school environment was more supportive.

News and information on education from government officials across states in Nigeria regarding the state of Education does not show any sign of improved commitment. For example, the Edo State government, through its Commissioner for Education (9 September 2009), announced a reduction in the number of public schools in the state from 627 to 295. This is another blow to education, as at the time mass illiteracy was being reported in Nigeria. In addition, teachers in the service of the Lagos State government embarked on a series of strike actions in 2009. A The Nation Newspaper, September 2009 reported that "there are indications that the strike embarked upon by the teachers in Lagos State may continue till 2010, as the state government has refused to engage in dialogue with them."

\subsection{Alternative jobs}

The children were asked whether they are currently involved in any jobs outside of school. Findings show that $86 \%$ are currently engaging in various forms of part-time and full-time businesses, and 14\% percent work with their parents on farms after school hours. Further investigation shows that $64 \%$ of those engaged in business were hawkers. This makes hawking the largest field of employment for children in the study areas. However, about $11 \%$ percent of the children combined hawking with other jobs; for example, $40 \%$ were once employed as housemaids at one time or another. They were 
employed by rich individuals for housework, and $84 \%$ of those who were housemaids complained that their monthly pay was not of a sufficient level to make future investments, even though they were properly fed in their employers homes. About 20\% were street beggars. Those engaged in street begging gave explanations for their involvement such as "the need to meet the basic necessities of life and the fulfillment of religious obligations. In some areas, some of these children are called "al-majeris". They go along the streets with plates begging for food and money. Tinuola (2009) reported in a study that $62 \%$ of children sampled in parts of Nigeria are poorly fed, which has led to an increased number of cases of illnesses arising from malnutrition at certain selected hospitals. $10 \%$ of some selected respondents working in the car washing business in order to raise money got temporary but daily work with adults who washed cars in strategic locations in the town. They are paid, daily, depending on the patronage of car owners. According to these respondents, charges depend on the nature/size of the cars and the status of the owners. The supporting services they are engaged in include fetching water, washing foot mats and cleaning car dash boards.

$12 \%$ of selected children engaged in foot washing and nail cutting to raise money for survival. They reportedly engaged in the business because it requires little capital to start and, though charges are fixed, in some circumstances they depend on the socio-economic status of the clients. Further investigation shows that hawking was mostly carried out in car parks, markets and various campuses of tertiary institutions where a large population requiring such services is available. Thirty-five percent were engaged as street vendors. This is reportedly common in the urban areas where most of them sell newspapers to motorists and passersby.

With the approval of operating licenses for mobile communication networks in Nigeria, the industry is viewed as one of the largest employers of labor in Nigeria. Children are not left out of the communication business. One-fifth of those involved in this survey were once or are currently engaged in businesses related to mobile communication. This includes sales of re-charging cards, retrieve of lost mobile lines, call services and other indirect services related to mobile communication services. These children establish communication kiosks along the streets where they render such services to the public.

\section{Why do children engage in labor?}

Fifteen percent of children were engaged in such businesses to save enough money to go back to school. Actually, the Universal Basic Education 
program provides a tuition-free education system in Nigeria, with little or no provision for other expenses associated with schooling. The idea of free primary education is basically to exempt pupils from school tuition fees; however, parents are responsible for other incidental and essential expenses such as textbooks, notebooks, school uniforms, and their children's health and nutrition. A further $20 \%$ of children are engaged in labor to support their family households with the aim of providing food, shelter and clothing to other members of family. These children complained that the businesses of their parents have not produced profit for family upkeep as a result of the current GEC. About $48 \%$ save money to acquire materials for self upkeep. A summary of this data shows that children are engaged in labor on the basis of their specific needs, most of which are associated with education and the other necessities of life.

\section{Hawking}

In this study, data show that most children carried out their businesses through hawking. Attempts are made below to explore hawking activities of children in the context of the data. In Nigeria, several studies have shown that hawking is done by young children of both sexes, but the greater proportion of hawkers are girls. Female hawkers come to urban or road junctions in groups and go in various directions to hawk their products. There are specific road junctions where they hawk daily and return to their respective villages after daily selling. In this study, $64 \%$ of the sample engaged in the hawking of different products. A significant finding is that the majority of the girls were not forced into hawking but did it as a last resort to enhance their living. They risk their lives by going in and out of traffic to sell products, typically congregating on busy streets at major intersections and, at times, impeding the free flow of traffic.

This section presents some qualitative and quantitative responses derived from interviews of selected women and children as regards hawking ventures. The reasons why some parents sent their children to hawk and various responses of parents in justifying the need to send their children to hawk are summarized in three different interview responses

A mother (a sixty year-old mother with no formal education, a trader) justified sending her daughter to hawk using these words:

"I am poor, I cannot feed my children, and business is not moving again. Government workers who bought goods from me on credit could not pay because their salary payments are irregular. I stopped the business when there 
was no money to continue the trade. The only choice was to buy little things for children to sell, or else we would go to bed hungry if they did not sell the goods I gave them to hawk. We literarily live on the proceeds from daily sales. The children hawk tomatoes, pepper, and eggs in the neighborhood".

The respondent above identified business failure as a result of the irregular payment of salaries of government workers and the consequent need to feed her family from the profits of hawking as the major motivation.

Corroborating the above, another mother (54 year-old woman with no formal education, widowed) said:

"I am a widow; my husband died eight years ago. I had no formal education. I was involved in petty trading and subsistence farming. I could not continue trading as a result of a terminal illness that has rendered me unproductive. The only choice I had was to send my little girl (thirteen years of age) with me to hawk some petty products. Now, I exist on whatever she brings home. She withdrew from school when we discovered that hawking could bring us enough profit to live. If she does not hawk these products, there will be no money to eat and we shall all die. So what do you expect us to do?"

The respondent above identified the death of her husband and her subsequent terminal illness. The need to feed her family resulted in her children dropping out of school and taking to hawking.

In another way, a woman (48 year-old, no formal education, separated) responded:

"My husband abandoned me with the kids because none of my six children are male and he preferred male children. I was rejected by members of his family. Since then, I have been carrying the burden of care for the children. I was employed as a junior staff member in one of the local councils. My take-home pay is not sufficient to care for the kids. Salaries are not paid as regularly as before and I decided to send two of my small girls to sell some products along the express road. The proceeds from the trade are used for feeding and caring for those in school".

The three responses summarize the noble words of women whose children were engaged in hawking products alongside major roads. In sum, reasons identified by the women include unpredictable business performance and/or failure, low salaries, family instability and poverty. They seem helpless, but must make ends meet. These data confirm the supposition that the involvement of children in street hawking is a consequence of the poor socio-economic conditions of parents.

In addition, a thirteen year-old girl explained that her father had died and there were three other children to care for, so being the oldest, she decided she would take care of family needs, and this could only be done only by 
street hawking, because the mother could not take care of their needs. The uneducated mother has no job.

Products hawked by children included assorted drinks (24\%), bread and groundnut (32\%), tomatoes and peppers $(18 \%)$, and bananas and other raw food items (26\%). They purchase these products daily from retailers and sell directly to consumers. Other goods the children hawk include groundnut oil, cooked and raw foods, vegetables, local crafts products, local drinks and jewelry. In a study, the non-governmental organization 'Home Front Lagos' found that children hawk goods to get money to feed and take care of the other basic needs of their families and that whenever they return home without making a profit, they are chastised and denied food.

\section{Years of hawking}

Questions were asked regarding the number of years children have spent hawking. An in-depth analysis of the data above shows that the hawking business became more popular about two years ago when the GEC began. This trend may increase if urgent measures are not taken to address the socioeconomic status of the children which is currently pre-determined by their parents. Findings of this study corroborate the data by Audu, Geidam and Jarma (2001) which shows that in most cities in Nigeria street hawking is taken for granted, such that people who have stalls and shops consider it good business practice to engage in hawking to increase sales.

Forty-five percent of children hawkers were not sent by their biological parents, as such persons are often sent away from their families to faraway places as hired help. Some of the children who dropped out of school reported they were taken away by relatives with the pretext of being assisted with their education, but ended up on the streets selling products.

However, findings of this study reveal that the girls that are mostly from rural areas where chances for enrolment into western schools are very limited, and thus for several reasons they are sent into cities to street hawk:

- The need to pay educational costs

- Feeding

- To supplement family income

- To meet personal needs

- To develop skills

However, interview results for this study show that whatever the reason for the involvement of the girl-child in street hawking, the underlining factor is 
poverty. Families who are not economically stable tend to send the girl-child from their homes to supplement the family's earnings through street hawking products for profit.

\section{Reported dangers of street hawking by girl child}

The dangers of street hawking were measured through responses from the selected children who took to street hawking. From their responses, the report below summarizes some of the risks to the health and well-being that children hawkers suffered in the course of carrying out their daily businesses since they dropped out of school. They are discussed under different sub-headings below:

\section{Sexual abuse}

About $8 \%$ of the children hawkers have suffered various forms of sexual abuse from adults, ranging from harassment to molestation and rape. The indepth responses in support of the above are quoted below:

A respondent explains:

"A man of 42 years of age, in a compound, bought my bread and cunningly lured me into buying him small quantity of milk and sugar. He cleverly entered his room and asked me to bring it in. I was ignorant of what the intentions of the man were and entered his room, but then the unexpected happened. He rushed and forced me, covered my mouth with a bathroom towel and had sex with me. Before that time, I had never done it before. There was blood all over my body. I had pains and shouted for help. Those who came to the scene took me to their house for a bath, shouted accusations at the man and convinced me that there was no need to tell my parents at home because my parents would beat me. I did not tell them, but when I remember that day, I am not always happy" (a thirteen year-old girl, bread hawker).

Another incidence of rape was reported by another respondent who shared the following experience:

"A 26 year-old boy had been buying bananas from me anytime I reached his house while hawking. So I took him to be a good customer. One day, around 11 a.m., he was alone in the compound when I came. He brought out water for me to drink, saying that the hot weather had affected me. I drank and thanked him, without knowing that the water contained some drugs that could intoxicate. I regained consciousness three hours later to discover that I 
had been raped. The case was reported to the police by my parents. The police wanted to take the case to court, but my parents insisted otherwise because of the possible social implications. My mother said no one would marry me if everyone knew I had been raped". (a fourteen year-old girl, banana hawker)

The above responses corroborate the findings of Tinuola (2005 \& 2006) that a significant proportion of children in Nigeria are victims of acts of sexual deviance, and most of these cases are not reported due to the perceived social stigma.

This form of violent sexual abuse, especially during childhood, can result in any nature of sociological, psychological and physical problems. During indepth interviews, respondents who had been reportedly sexually abused had at one time or another experienced one or some combination of the following: fears, panic attacks, self-harming, depression, self destruction, little confidence in other people and fear of loss of control in relationships. Physical problems reported by some people who reported sexual abuse include pain during sex, abdominal pain, menstrual pain and intestinal complaints and problem with orgasm.

The instances cited indicate that the sexual abuse of young girls was perpetrated by older boys/men who cunningly tricked them. Some of the cases of rape and sexual violence associated with hawking were not reported for prosecution in a court of law. The main reason for the non-reporting and resultant failure to prosecute is associated with the social stigma and the possibility of being tagged a "victim of rape". Consequences of sexual violence range from social stigma, cuts to the vagina, damage to the reproductive organ, unintended pregnancies, and the contraction of sexually transmitted infections resulting in primary and secondary infertility. In Nigeria, various National AIDS and Reproductive Health Survey Reports indicate greater challenges regarding reproductive health problems caused by the violent nature of this type of sex, with a call for a more pro-active action to arrest the situation, especially among the younger generation.

\section{Kidnapping/Murder}

Another interviewee narrated her experience in her native language, which was translated as follows:

"One day, we were almost finishing up our trading activities along the express road when a black Jeep pulled up. The occupants demanded cold water, and we rushed there in anticipation to sell. Then something terrible occurred when three of our girls were forced to enter the car and were driven 
away to an unknown destination. Those of us remaining quickly ran into the bush to escape and safety. We reported the case to their parents who reported it to the police. Two days later, the dead bodies of two of the three girls were found in an uncompleted building in another village, and it was discovered that their reproductive organs had been mutilated and cut off for use in rituals. The third girl has not been found until today. We did not go to that side of the road for some time, but had no option other than to return because that portion of the road is bad and vehicles slow down in an attempt to avoid potholes, and there the drivers request drinks and snacks from us" (a twelve year-old girl, groundnut hawker).

The above data detail the case of a kidnapping of three children hawkers, two of whom were killed, and a third has not yet been found.

"My good friend Aminat and I left school one day to fetch water to sell in the neighborhood in order to buy Social Studies textbooks. The borehole is located on the outskirts of the village. We fetched and sold many buckets of water until a man suddenly appeared from the nearby bush and administered traditional medicine on her, She became unconscious immediately, and was taken away. I ran back to report this, but before people could come, the man had left. Till today, we haven 't been able to find my friend again. God will not forgive that man"... (a twelve year-old female hawker).

\section{Opportunities for attending school}

The young girl hawker forfeits formal school, Western or Islamic education for hawking. She loses the opportunity to attend schools and thereby loses all the benefits of an education. Those who dropped out of school because of the socio-economic conditions of their parents caused by the current GEC may not return to classrooms if the current economic situation does not improve. The opportunity to acquire the necessary skills required to obtain good employment will elude them. Some of the children, as a result, end up doing menial jobs that may be detrimental to their health and wellness. They engage in jobs that require little or no skill, thereby limiting the extent to which they can get quality employment. Data in this study show that $15 \%$ of the selected children interviewed had already dropped out of school completely. The future of young girls who drop out of school appears bleak. In lacking a required and basic minimum certificate of education they may have difficulty getting gainful employment, resulting in their involvement in menial jobs which are hazardous to their health and well being. This may contribute to 
low life expectancy, high mortality among children and an increased number of teenage mothers.

\section{Deviant behavior}

The girl child is exposed to deviant behavior while street hawking which potentially turns her into a juvenile delinquent. The competitive nature of the environment where children work as hawkers provides a space for them to exhibit deviant behavior. There were reports that most of the girls involved in hawking engaged in and facilitated acts of sexual promiscuity and perversion. It was also reported that, out of five suspected teenage cult members arrested by the police in Abia State in August, 2009, only one of them is currently in school while the others have dropped out as a result of the inability of their parents to take care of the financial needs of their education.

\subsection{Results of table statistics}

Variables were cross tabulated on the basis of responses to validate or invalidate the propositions. Results are provided below:

\section{Position 1 \\ Children dropping out of school/socio-economic conditions of parents}

A child's dropping out of school is significantly correlated to the socioeconomic conditions of their parents as caused by the current GEC. Responses on "children drop out of school and the income of parents" were cross tabulated and tested through the use of the Chi square technique. The chi square result shows that $\mathrm{X}_{\mathrm{C}}{ }_{\mathrm{C}}=34.72$ while the degrees of freedom were $4 . \mathrm{X}_{\mathrm{t}}^{2}$ $=13.27$ at a 0.01 level of significance. Since the calculated value is greater than the table value, we accept the alternative hypothesis, which states that the proportion of children who drop out of school is significantly correlated to the poverty (and irregular income) of their parents, as predetermined by the current GEC's effect on their occupations. The data show that children who dropped out of school have parents who were low income earners. Any effort at positively influencing the income of the parents will reduce the rate of their children dropping out of schools. 


\section{Position 2 \\ Child sexual abuse/location of alternative jobs}

The incidence of child sexual abuse is significantly correlated to the nature of alternative jobs. To test the hypothesis, responses on the nature of jobs and the reported cases of child sexual abuse were used. The Chi square result shows that $\mathrm{X}_{\mathrm{C}}{ }_{\mathrm{C}}=41.5$ while the degrees of freedom were $4 . \mathrm{X}_{\mathrm{t}}^{2}=3.481$ at a 0.05 level of significance. Since the calculated value is greater than the table value, we can accept the alternate hypothesis. Therefore the place where alternative jobs are carried on by the children is a major determinant of their being sexually abused. Those who hawk in crowded markets were less likely to be sexually abused while those who hawk along major roads, junctions and hotels reported a higher number of cases of sexual abuse. Tinuola (2003) had earlier reported that the poor socio-economic conditions of parents led to their children's involvement in hawking in places that are dangerous to their health.

\section{Position 3}

\section{Menial jobs and intention to go back to school}

With more savings from menial jobs, will children engaged in labor go back to school? The above research question was tested with the Pearson coefficient was found to be 0.98 . With the significance level at 0.05 , the data indicate that the hypothesis is valid. This shows that children who dropped out of school and engaged in menial jobs had a tendency to go back to school if they saved enough money from their businesses. About $70 \%$ of the children who dropped out indicated their readiness to go back to school if their economic conditions improved. Initiating a comprehensive implementation plan for the Child Right Acts for free and compulsory education will improve the rate at which child drop outs return to school.

\section{DISCUSSIONS}

On the basis of the data obtained in this study, the correlation between this presentation and the role of policy formulation and implementation are listed below:

Dwindling revenues accruing to states from account of the federal government caused by the fall in the price of crude oil on the world market. 
Projects that were awarded to contractors who employed some parents were abandoned, and some workers were subsequently sacked.

The inability of states and local governments to pay the monthly salaries of workers. This affects the finances of parents and reduces purchasing power in support of their children's education.

Job Losses. The sacking, in August 2009, of all the teachers in the service of the Teaching Commission who hold Grade II Certificates in one of the states and the reduction in staff strength of major establishments of the government.

A drop in business activity resulting in low sales. Parents of children interviewed complained of low sales and high amounts of credit, resulting in high amounts of bad debts.

The GEC has recently affected five major banks in Nigeria. In August 2009, the governor of the Central Bank of Nigeria sacked the managing directors of five banks for incurring a huge amount of losses on non-performing loans. Most loans issued by the banks were non-performing because they were sunk into businesses that are unprofitable again as a result of the GEC. Many borrowers could not afford to service them. In July 2009, the CEO/MDs of five major banks in Nigeria were sacked on account of huge non-performing loans. On 5 September 2009, they were arraigned in court on charges of professional ineptitude for issuing loans without obtaining equivalent collateral securities.

\section{CONSEQUENCES}

The consequences of the above conditions are visible in the colossal loss of jobs due to sacking from government establishments, a loss of jobs due to the termination of some contracts that offered employment, a drop in business activities due to poor sales, a low rate of turnover and high levels of bad debts, an increased rate of children dropping out from school due to their inability to afford school expenses, child labor: the increased involvement of children in alternative jobs such as house help and hawking to support family household, sexual abuse of children and poor dietary habits resulting in malnutrition. 


\section{CONCLUSION/RECOMMENDATION}

It is obvious from the analysis undertaken in the course of this research that the well-being of Nigerian children depends on the socio-economic conditions of their parents. Research has also proved that the current GEC has significantly affected the income, occupation and other earnings of most parents. They now have difficulty providing adequate care for their children's education. Educating girls and young women is one of the most powerful ways of breaking the poverty trap. The proportion of children who have dropped out of school has increased and many of them are now engaged in alternative jobs that are risky to their health and well-being. This is a major challenge in an era where the literacy level is very low in most countries of sub-Saharan Africa, including Nigeria. With the current state of the Nigeria child, the achievement of the Millennium Development Goals on children and Child Right's Acts is far from a reality. Aside from the inability of the Nigerian government to create a separate ministry to care for children, the lack of an indigenous child policy and the exclusion of children from discussion on issues affecting them are problematic areas to be addressed. Aside from imposing a legal ban on child labor as stipulated in the Child Right's Acts, a reduction in hawking activities among children on the highway will reduce the incidence of child sexual abuse. Policies aimed at stabilizing the economic situation of parents and initiating a specific welfare package for children and a more proactive attitude backed by appropriate legal instruments are required implementation strategies for improving the state of the Nigerian child.

\section{REFERENCES}

"Council seeks Improvement in girl-child emolument" The Nation Newspaper, Monday, August 21, 2009.

National Population Commission (2006), The Preliminary report of the 2006 population and housing census in Nigeria

NARHS (2005) National AIDS and Reproductive Health Survey, Federal Ministry of Health, Nigeria

Nigeria: 11 million Nigerian children out of school Posted by africanpress on April 25, 2008 Publisher: The Punch Nigeria

Oguntimehin, C. F. (1992) "The nature and pattern of multiple sexual contacts in Ekiti District, Ondo State". M.Sc thesis submitted to the Department of Demography and Social Statistics, Obafemi Awolowo University, Ile Ife, Nigeria.

Tinuola, F. R. (2003), "Pre-marital Teenage Pregnancies in Odo Oro", University of Ado Ekiti Journal of Education Vol. 3 No.1, pp 112-123. 
Tinuola Femi (2005) “Adolescents' Sexual and Reproductive Health Behaviors in Ekiti". An unpublished PhD thesis submitted to the Department of Sociology, University of Ado Ekiti, Nigeria

Tinuola, F. R (2006), “Analysis of some key sexual behavior Indicators among younger women in Ekiti Southwest Nigeria”, The Social Sciences Vol. 1 No.3, pp $172-177$

Tinuola Femi (2009), "Nutrition and the Vulnerability of children to unbalanced dietrelated diseases in Nigeria" Child Poverty: Public Policies for Social Justice. Egypt National Child Rights Observatory 2009 - 2010 pp 355 - 372

http://go.worldbank.org/FTD World Development Report 2010: Development and Climate Change, Published September 15, 2010 